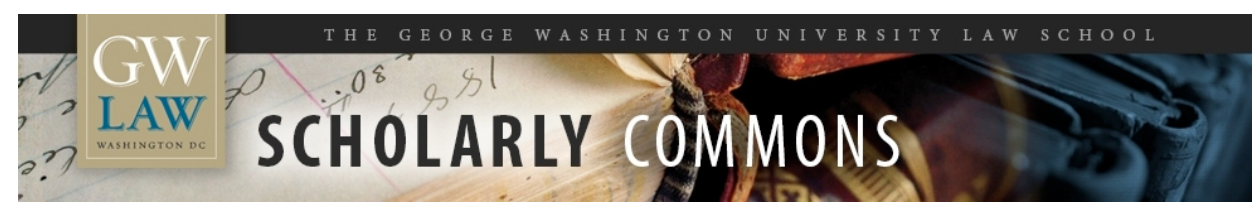

\title{
From Legal Pluralism to Global Legal Pluralism
}

\author{
Paul Schiff Berman \\ George Washington University Law School, pberman@law.gwu.edu
}

Follow this and additional works at: https://scholarship.law.gwu.edu/faculty_publications

Part of the Law Commons

\section{Recommended Citation}

Berman, Paul Schiff, From Legal Pluralism to Global Legal Pluralism (2014). GWU Law School Public Law Research Paper No. 2015-20; Law, Society and Community Socio-Legal Essays in Honour of Roger Cotterrell, Richard Nobles \& David Schiff, ed., Ashgate, 2014 ; GWU Law School Public Law Research Paper No. 2015-20; GWU Legal Studies Research Paper No. 2015-20. Available at SSRN: http://ssrn.com/ abstract $=2609369$

This Article is brought to you for free and open access by the Faculty Scholarship at Scholarly Commons. It has been accepted for inclusion in GW Law Faculty Publications \& Other Works by an authorized administrator of Scholarly Commons. For more information, please contact spagel@law.gwu.edu. 


\section{Law, Society and Community Socio-Legal Essays in Honour of Roger Cotterrell}

Edited by

RICHARD NOBLES AND DAVID SCHIFF

Queen Mary University of London 


\title{
Chapter 15
}

\section{From Legal Pluralism to Global Legal Pluralism}

\author{
Paul Schiff Berman ${ }^{1}$
}

\section{Introduction}

Legal pluralists have long recognized that societies consist of multiple overlapping normative communities. These communities are sometimes state-based but sometimes not, and they are sometimes formal, official and governmental, but again sometimes they are not. Scholars studying interactions among these multiple communities have often used the term 'legal pluralism' to describe the inevitable intermingling of these normative systems. ${ }^{2}$ The study of plural normative systems has arisen from a variety of different scholarly traditions. Perhaps the earliest studies of the clashes between state and non-state authority were those penned by lawyers, philosophers and theologians interested in the respective realms of Church and State authority (see, e.g., Figgis 1913). Likewise, historians analyzing the regulatory role of non-state entities such as jockey clubs and stock exchanges noted that these entities often wield more power than formal state law (see, e.g., Maitland 1936). Anthropologists used the idea of legal pluralism to conceptualize the relationship between colonial and indigenous legal systems (see, e.g., Pospisil 1981). And social norms theorists (see, e.g., Ellickson 1991) and scholars in behavioural law and economics (see, e.g., Jolls et al. 1998) have become interested in forms of informal law that often regulate behaviour as much or more than official governmental pronouncements.

In recent years, a new application of pluralist insights has emerged in the international and transnational realm. This new legal pluralism research was born in the decades following the collapse of the bi-polar Cold War order in 1989. During this period, it became clear that a singleminded focus on state-to-state relations or universal overarching norms was inadequate to describe the reality of the emerging global legal system, with its web of jurisdictional assertions by state, international and non-state normative communities. As one commenter puts it:

The nation-state and the interstate system are the central political forms of the capitalist world system, and they will probably remain so for the foreseeable future. What has happened, however, is that they have become an inherently contested terrain, and this is the central new fact on which the analysis must focus: the state and the interstate system as complex social fields in which state and nonstate, local and global social relations interact, merge and conflict in dynamic and even volatile combinations. (Santos 2002: 94)

1 Some of the material in this chapter is derived from Berman 2012 and 2009.

2 The history of 'legal pluralism' is a matter of debate. Some associate the term with legal anthropology (see, e.g., Tamanaha 1993; Merry 1988), while others (see, e.g., Benda-Beckmann 1997) trace the use of the term to lawyers (Hooker 1975). Still others see legal pluralism deriving from Church/State conflicts-oflaw analysis (see, e.g., Galanter 1981: 28). For discussions of the history of 'legal pluralism', see BendaBeckmann 1997; De Sousa Santos 1987; Griffiths 1986; Merry 1988; Tamanaha, 1993; Vanderlinden 1989. 
Legal pluralism provided a useful alternative framework because pluralism had always sought to identify hybrid legal spaces, where multiple normative systems occupied the same social field. And though pluralists had often focused on clashes within one geographical area, where formal bureaucracies encountered indigenous ethnic, tribal, institutional or religious norms, the pluralist framework proved highly adaptive to analysis of the hybrid legal spaces created by a different set of overlapping jurisdictional assertions (state v. state; state v. international body; state v. non-state entity) in the global arena. ${ }^{3}$

An emphasis on legal pluralism also freed scholars from endless intractable debates about whether international law is truly law given that coercive enforcement power in the international and transnational arena is often indirect or non-existent. Such debates had created stagnation in the international law and international relations literature as both international law triumphalists and nation-state sovereigntists talked past each other with either an overly formalist faith in international law's inherent authority, on the one hand, or an overly formalist rejection of any law beyond the nation-state, on the other.

Global legal pluralism applies the insights of socio-legal scholarship and turns the gaze away from abstract questions of legitimacy and towards empirical questions of efficacy. Thus, pluralists deemphasize the supposed distinctions between a norm, a custom, a law, a moral command, a sociological consensus, a psychological imperative or the like. Instead, a pluralist approach focuses on whether people in actual practice perceive such legal or quasi-legal commands to be binding, whether such commands seep into consciousness over time, and whether the existence of these alternative norms alter the power dynamics or options placed on the table in policy discussions. Finally, global legal pluralism has both a descriptive and normative component. Anthropologists and historians have generally framed the study of legal pluralism in descriptive terms. Accordingly, they have catalogued the inevitable hybridity that arises when two legal or quasi-legal systems occupy the same social space, as well as the resulting strategic interactions that occur among actors in navigating the multiple regimes. As a descriptive enterprise, legal pluralism is relatively uncontroversial. After all, even the most die-hard sovereigntist would likely acknowledge that sub-, supra-, or non-state normative systems do impose real constraints that have real impacts. More controversial is the idea that legal pluralism might be a normatively desirable approach to the design of legal systems.

As a normative project, legal pluralism can be seen to support two different strategies. First, what we might call substantive legal pluralism seeks accommodation of alternative norms, at least in certain delineated spheres. This is more of a multiculturalist project, and for purposes of this chapter I will set it aside. Second, a more proceduralist vision of legal pluralism aims to design procedural mechanisms, institutions and discursive practices that seek to manage pluralism, without making a priori substantive decisions regarding when deference to alternative norms is appropriate and when it is not. This proceduralist version of legal pluralism's normative project argues that the mechanisms, institutions and practices that result may at times be preferable to either sovereigntist territorialism on the one hand, or universal harmonization on the other. Moreover, such a proceduralist version of legal pluralism, unlike the substantive version, need not commit one to a programme of inevitable deference even to illiberal norms. Nevertheless, this proceduralist approach, precisely because it refuses to engage with some of the most contentious

3 In that sense, we might more accurately refer to the 'global legal system' as a 'multiscalar legal system'. For example, Hari Osofsky 2007 has argued that the term 'multiscalar' more accurately captures the variety of normative communities with input at different 'levels' of the legal hierarchy than does the word 'global'. 
substantive political battles over when deference is appropriate and when it is impossible, may be distrusted or rejected by those on both sides of the pluralism debate who want more substantive normative certainty.

Among his many other accomplishments as a legal theorist, Roger Cotterrell was one of the first scholars to recognize this pluralism in the sub-national, trans-national and supra-national legal arena (Cotterrell (1995), at 281). And more than simply recognize the phenomena, he made two distinct contributions that have provided a touchstone for subsequent scholars. First, he offered a far more flexible and capacious definition of law - law as institutionalized doctrine than is typical among legal theorists, but one that is not so capacious that it falls victim to the concern that any normative assertion will be deemed to be law (Cotterrell 1995: at 31-2). Thus, for legal pluralists sceptical of formalist definitions of law, but worried that having no working definition will be problematic, Cotterrell's approach provides a crucial building block. Second, Cotterrell (2006) developed a typology of types of community: instrumental, traditional, beliefor values-based and affective. In a world of legal pluralism, different normative communities vie for authority, and though we are accustomed to defining legal communities solely by reference to territory, there are numerous reasons why such a community definition is unsatisfying (see Berman 2002). In contrast, Cotterrell's typology of community provides flexibility and space for rethinking rigid legal categories. Accordingly, Cotterrell's contributions to the global legal pluralist framework are significant and likely to be influential for many years to come.

In honour of Roger, then, I seek in this chapter to summarize and further refine the move from legal pluralism to global legal pluralism by discussing each component of the inquiry further: in what way is global legal pluralism 'global'; in what way 'legal'; and in what way 'pluralist'? This analysis prompts investigation both of challenges to the global legal pluralist project as well as possible responses to those challenges.

\section{Is Global Legal Pluralism Global?}

The word 'global' - along with its related word 'globalization' - has been widely used in recent decades to describe the post-Cold War era, but it is fair to say that there is no clear consensus on what we mean when we use the word. For example, if by 'global' we mean only the legal rules governing relations among territorially distinct nation-states, we could use the tried and true word 'international' and speak of international legal pluralism. In contrast, if we mean to invoke a single set of norms or procedures applicable around the globe, what we really mean is a kind of universalism or a unitary set of principles, and we might call it 'universal' legal pluralism (which is likely an oxymoron). The question therefore is whether the word 'global' captures something essential that would otherwise be missed.

I think it does. Indeed, global legal pluralism occupies a crucial cosmopolitan middle ground between what we might call sovereigntist territorialism on the one hand, and universalism on the other. Thus, neither 'international' nor 'universal' fits the bill. It is worth taking a moment to understand why. Recall that the central insight of global legal pluralism is that we live in a world of hybrid legal spaces, where multiple normative regimes may govern (or at least strongly influence) our activities and authority tends to be relative, not absolute. For example, the growth of global communications technologies, the rise of multinational corporate entities with no significant territorial centre of gravity, and the mobility of capital and people across borders mean that many jurisdictions will feel effects of activities around the globe, leading inevitably to multiple assertions of legal authority over the same act, without regard to territorial location. 
The problem of multiple states' asserting jurisdiction over the same activity is just the tip of the iceberg, however, because nation-states must also often share legal authority with one or more international and regional courts, tribunals or regulatory entities. Indeed, there are now over a hundred international courts and tribunals, all issuing decisions that have some effect on state legal authority, though those decisions are sometimes deemed binding, sometimes merely persuasive and often fall somewhere between the two. Finally, non-state legal (or quasi-legal) norms add to the hybridity. Given increased migration and global communication, it is not surprising that people feel ties to, and act on the basis of affiliations with, multiple communities in addition to their territorial ones. Such communities may be ethnic, religious or epistemic; transnational, subnational or international; and the norms asserted by such communities frequently challenge territorially
based authority.

Sovereigntist territorialism represents a retreat from this messy hybrid world of multiple overlapping normative authority. Instead, the state-centric view of the world rests on the convenient fiction that nation-states exist in autonomous, territorially distinct, spheres and that activities therefore fall under the legal jurisdiction of only one regime at a time. Thus, traditional legal rules have tied jurisdiction to territory: a state could exercise complete authority within its territorial borders and no authority beyond it. In the twentieth century, such rules were loosened, but territorial location has remained the principal touchstone for assigning legal authority.
Accordingly, if one could spatially ground a dispute, one could most likely determine the legal rule that would apply. But consider such a system in today's world. Should the US government be able to sidestep the US Constitution when it houses prisoners in 'offshore' detention facilities in Guantánamo Bay or elsewhere around the world? Should spatially distant corporations that create serious local harms be able to escape local legal regulation simply because they are not physically located in the jurisdiction? How can we best understand the complex relationships among international, regional, national, and subnational legal systems? Does it make sense to think that satellite transmissions, online interactions and complex financial transactions have any territorial locus at all? When the US government seeks to shut down the computer of a hacker located in Russia, does the virus transmitted constitute an act of war or a violation of bodies, non-governmental organizations, religiou-state actors such as industry standard-setting and others exert significant normative pull, can we build a sufficiently capacious understanding of the very idea of jurisdiction to address the incredible array of overlapping authorities that are
our daily reality?

Thus, a simple model that looks only to territorial delineations among official state-based legal systems is now simply untenable (if it was ever useful to begin with). Thankfully, debates about globalization have moved beyond the polarizing question of whether the nation-state is dying or not. But one does not need to believe in the death of the nation-state to recognize both that physical location can no longer be the sole criterion for conceptualizing legal authority and that nationstates must work within a framework of multiple overlapping jurisdictional assertions by state, international and even non-state communities. Each of these types of overlapping jurisdictional assertions creates a potentially hybrid legal space that is not easily eliminated. The influence and application of foreign norms or foreign decision-making bodies may be useful and productive or alien and threatening, but in any event they are inevitable and cannot be willed away by fiat.

Moreover, global legal pluralism recognizes the possibility that at least sometimes this pluralism of normative authority may be preferable to a system that imposes a single authority because the reality of legal pluralism empowers individuals to strategically operate among normative and procedural regimes. In a world of multiple overlapping legal and quasi-legal 
systems, there are always multiple ports of entry. An argument unheard in one forum can gain traction in another. A norm articulated in one place can be persuasive elsewhere. The powerless in one system can access power in another. As Robert Cover (1981) recognized decades ago, there are inherent advantages to a system 'that permits tensions and conflicts of the social order' to be played out in the overlapping jurisdictional structure of the system itself. Of course, powerful repeat players can also strategically use such a plural system to shop for desired norms. Thus, the mere existence of global legal pluralism does not magically level the playing field among parties of disparate power or render such power disparities irrelevant. But there can be little doubt that jurisdictional pluralism opens up discursive space, providing opportunities for agency that may not have existed previously.

As with sovereigntist territorialism, universalism also represents a retreat from the hybrid legal spaces of a pluralist world. Here, instead of responding to normative difference by seeking to impose a single local authority, we see the desire to erase normative difference altogether. Indeed, international legal theory has long yearned for an overarching set of commitments that would establish a more peaceful and harmonious global community. This supposed new world order variously focuses on the religiously-based natural law principles of international human rights or the neoliberal ideology of free trade and its need to harmonize rules that regulate commerce.

One cannot discount the importance of universalism. Certainly since World War II we have seen the creation of a dizzying array of international institutions, multilateral and bilateral treaties, conventions, cross-border regulatory coordination efforts, and the like. In one way or another, all of this activity represents the desire to harmonize conflicting norms. And on many fronts, both in public and private law, norms are in fact converging to a degree, whether through hegemonic imposition or global embrace. Moreover, such harmonization has important benefits because it tends to lower transaction costs and uncertainty as to what norms will be applied to any given activity. Yet, there are reasons to question both the desirability and - more importantly - the feasibility of universalism, at least in some contexts. This is because universalism is based on the premise that people are fundamentally the same despite differences in culture and circumstance. In contrast legal pluralism, founded as it is on anthropological observation (and celebration) of cultural difference, rejects the idea that we should ever expect or necessarily encourage uniformity. From such a perspective, universalism's efforts to dissolve the multi-rootedness of community affiliation into one overarching identity is inherently problematic because it fails to capture the extreme emotional ties people still feel to distinct national or local communities. As Thomas Franck (1996: 374) put it, 'The powerful pull of loyalty exerted by the imagined nation demonstrates that, even in the age of science, a loyalty system based on romantic myths of shared history and kinship has a capacity to endure'. This is what universalism tends to ignore: the very attachments people hold most deeply.

In addition, universalism inevitably erases diversity. Indeed, the whole point of a universalist or harmonization solution is to combat diversity or fragmentation. Yet, although one can appreciate the goal, erasing diversity may involve the silencing of less powerful voices in the global conversation. Thus, the presumed universal may also be the hegemonic. This argument is most often heard by those who resist international human rights norms because they may run roughshod over important local practices, customs or perspectives. For example, in response to the presumed universality of the Universal Declaration of Human Rights, some scholars wonder what such a declaration can mean 'in a universe of competing values and moralities? Is there an objective technique for evaluating systems of morals and cultures? Given the specificity of cultural standards and values, and given the predisposition of human beings to generalize from their situated perspectives and realities, how can we ensure that our presumptions and assertions of universality are not veiled 
projections onto others of our moral categories?' (Obiora 1997: 277-8). Such arguments have arisen most famously in debates about eradicating the practice of female genital cutting, practiced in many communities on the African continent. On the one hand, many condemn and combat the practice as a violation of women's human rights. At the same time, others suggest that such a position fails to understand the local meaning of the practice. As one scholar argues, "In the eyes of the Neo-Agrarian cultures of today's Africa, the customary ritual practices of both male and female circumcision are seeable by their practitioners as the supernaturally prescribed, and therefore, indispensable condition of being human' (Wynter 1997: 504-5). Thus, critics contend that the presumed universal tends to become a western or northern imperialist imposition on less powerful communities. In this debate we see replayed the insistence on universal imposition on the one hand and the pristine integrity of the local community on the other. Both positions are retreats from hybridity. In contrast, a global legal pluralist vision focuses on the interactions between these two positions: the ways in which local actors deploy the universalist language of human rights to advance positions strategically, the ways in which so-called local voices interact with seemingly international ones to create change to internationalist regimes and assumptions, and so on. Only through this sort of interactive vision can we avoid reifying either the universal or the local. The word global invokes this multi-rooted process rather than dissolving it into sovereigntist localism or universalism.

\section{Is Global Legal Pluralism About Law?}

Most critical resistance to legal pluralism has historically revolved around the concern that pluralism's capaciousness as an analytical approach renders it unhelpful because it does not offer a definition of where law begins and ends or how to differentiate law from normative pronouncements that are not law. In this debate, we see that one of the strengths of legal pluralism - decoupling the idea of law from governmental power - becomes a liability. Nevertheless, I think a strong argument can be made that, especially in the context of global legal pluralism, the usefulness outweighs the liability. This is because international law debates are often sidetracked by abstract questions regarding whether legal norms asserted by non-nation-state actors are sufficiently lawlike to be worthy of attention. Such legal norms might be expressed by nation-states seeking to impose norms extraterritorially, or they might be promulgated by international bodies, or by private non-state entities or multinational corporations. But regardless of the source, much is lost if we try to cabin the study of law on the global scene only to the official pronouncements of nationstates backed by the threat of coercive force. The enforcement power of a norm matters, of course, and power disparities matter as well. But we are unlikely to understand the evolving system of transnational norm creation unless we expand our definition of law.

Legal (or quasi-legal) norms have real impact even in the absence of enforcement power for at least three reasons. First, even if one focuses on state actors pursuing their own interests, those state interests do not exist independently of the social context within which they are formed. Indeed, a policymaker's idea of what is in the state's interest is always and necessarily affected by ideas of appropriate action. And these ideas, in turn, are likely to be shaped - even if unconsciously - by legal norms, including the norms of non-state or international law. Moreover, such government officials, especially in a democracy, are at least somewhat responsive to popular opinion, and such opinion is also likely to be shaped by a variety of forces, again including the moral pull of nonstate or international legal norms. As socio-legal scholars have long described, legal norms can effect changes in legal consciousness that in turn alter the categories of our thought, such that they 
help determine what we are likely to see as a viable policy option in the first place. Accordingly, coercive power is not the only way that law can have an effect, either domestically or internationally. As Martha Finnemore (1996: 15) has noted, '[s]ocially constructed rules, principles, norms of behavior, and shared beliefs may provide states, individuals, and other actors with understandings of what is important or valuable and what are effective and/or legitimate means of obtaining those valued goods'. As a result, law has an impact not merely (or perhaps even primarily) because it keeps us from doing what we want. Rather, law changes what we want in the first place.

In this respect, legal pluralism research can be useful, because it analyzes how the existence of legal or quasi-legal norms changes legal consciousness over time. Legal consciousness scholars have sought to study empirically just how it is that legal categories become reflected in ordinary discourse and thought. Indeed, such scholars have argued that law operates as much by influencing modes of thought as by determining conduct in any specific case (e.g., Bumiller 1988: 30-32; Ewick and Silbey 1998; McCann 1994: 7; Merry 1990; Silbey 1992: 42). Law is a constitutive part of culture, shaping and determining social relations and providing 'a distinctive manner of imagining the real' (Geertz 1983: 173). For example, '[1] ong before we ever think about going to a courtroom, we encounter landlords and tenants, husbands and wives, barkeeps and hotel guests roles that already embed a variety of juridical notions' (Sarat and Simon 2001: 20). Indeed, we cannot escape the categories and discourses that law supplies. These categories may include ideas of what is public and what is private, who is an employer and who is an employee, what precautions are 'reasonable', who has 'rights', and so on. In short, 'it is just about impossible to describe any set of "basic" social practices without describing the legal relations among the people involved-legal relations that don't simply condition how the people relate to each other but to an important extent define the constitutive terms of the relationship ...' (Gordon 1984: 103). Because legal categories and ideas suffuse social life, scholars have studied both how people think about the law and the ways in which largely inchoate ideas about the law can affect decisions they make. Sally Engle Merry observes legal consciousness in "the way people conceive of the "natural" and normal way of doing things, their habitual patterns of talk and action, and their commonsense understanding of the world' (Merry 1990: 5). These understandings are often taken for granted. This is because legal consciousness may be so much a part of an individual's worldview that it is present even when 'law' is seemingly absent from an understanding or construction of life events. Thus, '[w]e are not merely the inert recipients of law's external pressures. Rather, we have imbibed law's images and meanings so that they seem our own' (Sarat and Kearns 1993: 29). Law is an often unnoticed, but nonetheless constitutive shaper of experience.

Of course, it is difficult to isolate or prove the precise impact of legal consciousness. Yet, the mere fact that changes in legal consciousness are difficult to quantify and predict does not render them any less important in analyzing state behaviour concerning international or transnational law. Indeed, there are simply too many instances when we do see state actors internalize the norms of international law to dismiss them as flukes or explain them away as mere strategic behaviour. Perhaps the best-known example of a change in international legal consciousness concerns the very idea of crimes against humanity. At the time of the Nuremberg prosecutions, it was not at all clear that the pre-war atrocities committed by the German government against German citizens constituted an international crime punishable outside Germany itself (Orentlicher 1991: 2555). Yet, the statute of the Nuremberg tribunal and the decisions of the tribunal effectively established such a crime. Then, subsequent to Nuremberg, almost every state for the first time voluntarily subjected itself to the Genocide Convention, further enshrining the idea that individuals might have international rights against their own nation-states. Today, this idea is sufficiently well accepted that we commonly see international prosecutions for crimes against humanity committed within 
state borders, and the International Criminal Court has jurisdiction over such crimes. Significantly, though the US has not ratified the International Criminal Court statute, the basic idea of a crime against humanity under international law is no longer seriously in doubt, signifying an important shift from World War II to the present day.

Just as importantly, it is sometimes not that an international regime is constraining states but that the regime creates the impetus for action in the first place. For example: Prior to the actions of UNESCO, most states, especially less developed countries, had no notion that they needed or wanted a state science bureaucracy. Similarly, European heads of state were not particularly concerned about treatment of the war wounded until Henri Dunant and the International Committee of the Red Cross made it an issue. Global poverty alleviation, while long considered desirable in the abstract, was not considered a pressing responsibility of states, particularly of developed states, until the World Bank under Robert McNamara made it a necessary part of development (Finnemore 1996: 12). Thus, the persuasive power of international norms caused states to develop interests they might not otherwise have had. In these instances, international law is shaping the consciousness of state actors, not operating through coercive restraint. Similarly, as Thomas Berger (1998) argues, in Germany and Japan today, antimilitarism is as crucial to national identity as militarism was in the World War II era. These are changes in the states' conceptions of their own interests, influenced by the international legal regime that Germany in particular has long championed.

Thus, we imbibe legal norms and cognitive categories even when we are not consciously aware of the norm in question. We are persuaded by legal norms even when those norms are not literally enforceable. We act in accordance with law because doing so has become habitual, not because we seek to avoid sanction. We conceive of our interrelations with others in terms of law because our long-term interests require that we do so, even when our short-term interest might seem to counsel otherwise. And the existence of a legal norm alters the constitutive terms of our relationships with others as well as the costs of noncompliance. All of these factors may be overcome in some circumstances. Indeed, people sometimes violate domestic law just as states sometimes violate international law. But in neither case does that mean that the law in question has no significant constraining force. And only by thinking more broadly about changes in legal consciousness and the complicated social, political and psychological factors that enter into the conceptualization of state interests can we begin to understand how international or non-state law operates.

Second, legal or quasi-legal norms have impact on states even absent enforcement power because states are not monolithic entities with a single, definable set of interests. Instead, states are made up of multiple bureaucrats with various spheres of authority, political ideologies, institutional loyalties and interests that range from the goal of re-election, to the need to curry favour with particular interest groups, to the aim of career advancement. And that is not even counting the myriad forces outside of government - NGOs, editorial writers, campaign contributors, political movements and so on - that all exert influence on government actors and all may themselves be influenced by and may consciously deploy the norms of international, transnational, and non-state legal norms in order to press varying agendas. For example, although the celebrated efforts of Spanish Judge Baltasar Garzón to try former Chilean leader Augusto Pinochet were not literally 'successful' because Pinochet was never extradited to Spain, they strengthened the hands of human rights advocates within Chile itself and provided the impetus for a movement that led to a Chilean Supreme Court decision stripping Pinochet of his lifetime immunity. Likewise, Spanish efforts to prosecute members of the Argentine military bolstered reformers within the Argentine government, most notably then-President Nestor Kirschner. In August 2003, Judge Garzón sought extradition from Argentina of dozens of Argentines for human rights abuses committed under the 
Argentine military government in the 1970s. In addition, Garzón successfully sought extradition from Mexico of one former Argentine Navy lieutenant who was accused of murdering hundreds of people. In the wake of Garzón's actions, realist observers complained that such transnational prosecutions were illegitimate because Argentina had previously conferred amnesty on those who had been involved in the period of military rule and therefore any prosecution would infringe on Argentina's sovereign 'choice' to grant amnesty (Rivkin and Casey 2003).

But the amnesty decision was not simply a unitary choice made by some unified 'state' of Argentina; it was a politically contested act that remained controversial within the country. And the Spanish extradition request itself gave President Kirschner more leverage in his tug-of-war with the legal establishment over the amnesty laws. Just a month after Garzón's request, both houses of the Argentine Congress voted by large majorities to annul the laws. Meanwhile the Spanish government decided that it would not make the formal extradition request to Argentina that Garzón sought, but it did so based primarily on the fact that Argentina had begun to scrap its amnesty laws and the accused would therefore be subject to domestic human rights prosecution. President Kirshner therefore could use Spain's announcement to increase pressure on the Argentine Supreme Court to officially overturn the amnesty laws. Finally, on 14 June 2005, the Argentine Supreme Court did in fact strike down the amnesty laws, thus clearing the way for domestic human rights prosecutions. Not only was the pressure exerted by Spain instrumental in these efforts, but it is significant that the Argentine Court cited as legal precedent a 2001 decision of the Inter-American Court of Human Rights striking down a similar amnesty provision in Peru as incompatible with the American Convention on Human Rights and hence without legal effect. So, in the end, the 'sovereign' state of Argentina made political and legal choices to repeal the amnesty laws just as it had previously made choices to create them. But in this change of heart we can see the degree to which international legal pronouncements, even if they are without any literal constraining effect, may significantly alter the domestic political terrain.

Likewise, official international institutions, such as the United Nations, can also pressure local bureaucracies by creating international commissions of inquiry concerning alleged atrocities, or by threatening prosecutions in international courts. Such declarations can empower reformers within local bureaucracies, who can then argue for institutional changes as a way of staving off international interference. For example, in the aftermath of the violence in East Timor that followed its vote for independence, there were grave concerns that the Indonesian government would not pursue human rights investigations of the military personnel allegedly responsible for the violence (Dickinson 2003a). Accordingly, an International Commission of Inquiry was established, and UN officials warned that an international court might be necessary. As with Chile and Argentina, such actions strengthened the hand of reformers within Indonesia, such as then-Attorney General Marzuki Darusman. With the spectre of international action hanging over Indonesia, Darusman made several statements arguing that, for nationalist reasons, a hard-hitting Indonesian investigation was necessary in order to forestall an international takeover of the process. Not surprisingly, when this international pressure dissipated after the terrorist attacks of 11 September 2001, so did the momentum to provide real accountability in Indonesia for the atrocities committed. Thus, we can again see that international legal activity (or the lack of it) alters the domestic terrain.

Indeed, even in the United States, the Oklahoma Court of Criminal Appeals stayed an execution in 2004 based in part on a prior decision of the International Court of Justice concerning the Vienna Convention on Diplomatic Relations, despite the fact that the international court had no means of literally enforcing its decision in Oklahoma (Berman 2007). And in the trade context, although ad hoc tribunals convened under Chapter 11 of the North American Free Trade Agreement (NAFTA) have no authority to directly reverse the decisions of national courts or create formally 
binding precedent, Robert Ahdieh (2004) has argued that, over time, we may see the interactions between the NAFTA panels and national courts take on a dialectical quality that is neither the direct hierarchical review traditionally undertaken by appellate courts, nor simply the dialogue that often occurs under the doctrine of comity. Instead, Ahdieh predicts that international courts are likely to exert an important influence even as the national courts retain formal independence, much as US federal courts exercising habeas corpus jurisdiction may influence state court interpretations of US constitutional norms in criminal cases. In turn, decisions of national courts may also come to influence international tribunals. This dialectical relationship, if it emerges, will exist without an official hierarchical relationship based on coercive power.

There can also be little doubt that local actors, outside of official government bureaucracies or judicial institutions, can at times leverage international and transnational legal norms to press causes within their countries. ${ }^{4}$ For example, as late as 1994 women in Hong Kong were unable to inherit land. That year a group of rural indigenous women joined forces with urban women's groups to demand legal change. As detailed by Sally Engle Merry and Rachel Stern (2005: 399), ' $[t]$ he indigenous women slowly shifted from seeing their stories as individual kinship violations to broader examples of discrimination'. Ultimately, the women learned to protest these unjust customary laws in the language of international human rights and gender equality. Having done so, they were successful at getting the inheritance rules overturned. While we might regret the fact that these women were forced to 'translate' their grievances into an internationally recognized language in order to be heard, the success of the movement in accessing political power surely attests to the strength and importance of the international law discourse.

Third, it is important to recognize that legal scholars often overestimate the degree to which formal legal pronouncements and institutions actually penetrate social life. As a result, they miss the many sites where the state is non-existent or ignored, or has limited or no power. They also tend to ignore all the coercive systems that get their authority from power centres separate from the state, whether those centres are religious institutions, ethnic or regional clans, or communities of practice. To take an oft-cited example, the international rules governing trade finance are promulgated by a community of bankers with no state involvement at all. Thus, the interaction among plural norms in the global arena cannot simply be viewed as a state pursuing a single set of interests either completely constrained or completely unconstrained by external norms that are either called 'law' or 'not law'. Rather, as part of the multivalent, messy process by which various state constituencies vie to have their preferred policies adopted, alternative legal and quasi-legal norms are a powerful tool, regardless of enforcement power. These norms provide a set of moral, rhetorical and strategic arguments that may empower constituencies that might not otherwise have a voice, or they may be used by already powerful forces to protect their own interests. In any event, only by going beyond a simplistic law/non-law dichotomy can we see the power of global pluralism coursing below the surface of the seemingly all-powerful state system.

4 Of course, such local actors do not only 'use' international law as 'given' to them, but also, through their social movements, shape the international legal norms themselves. For an argument that human rights discourse has been fundamentally shaped by Third World resistance to development, see generally Rajagopal 2003. 


\section{Is Global Legal Pluralism Really Pluralist?}

As noted previously, global legal pluralism functions as a middle ground position between sovereigntist territorialism on the one hand, and universalism on the other. As a result, both hardline sovereigntists and committed international law triumphalists tend to criticize pluralism from their differing perspectives. Sovereigntists think global legal pluralism pays insufficient attention to nation-state prerogatives and is really just universalism in another guise. And universalists tend to view global legal pluralism as giving too much play to parochial local and state-based interests.

So, is global legal pluralism really pluralist, and, if so, what practical benefit does the pluralist approach provide? Given the descriptive reality of global legal pluralism, we should not be at all surprised to find, across a wide variety of doctrinal areas, the development of procedural mechanisms, institutions and discursive practices that attempt to manage the overlapping of legal or quasi-legal communities. Nevertheless, viewing such doctrines through a pluralist lens as a normative matter may offer an important alternative perspective on their efficacy or functionality. Indeed, even if we accept that these mechanisms, institutions and practices are often the product of necessary political compromise between sovereigntist territorialism and universalism, global legal pluralism views these systemic compromises as creating a context for interaction and conversation among multiple constituencies. In consequence, the resulting solution may actually be seen as better than if either sovereigntism or universalism had won because it allows for more voices, more input from different perspectives, and more participation from different communities. This pluralist participation may make the resulting decisions more likely to gain support (or at least acquiescence), but the decisions also may be substantively better because more perspectives are included. In any event, it is clear that global legal pluralism offers a distinct perspective that neither sovereigntism nor universalism provides.

Consider two examples to illustrate the point. First, the oft-discussed 'margin of appreciation' doctrine allows the European Court of Human Rights (ECtHR) to pursue a rights agenda while maintaining space for local variation (e.g., Helfer and Slaughter 1997: 316-17). The idea here is to strike a balance between deference to national courts and legislators on the one hand, and maintaining 'European supervision' that 'empower[s the ECtHR] to give the final ruling' on whether a challenged practice is compatible with the Convention, on the other. Thus, the margin of appreciation allows domestic polities some room to manoeuvre in implementing ECtHR decisions in order to accommodate local variation. How big that margin is depends on a number of factors including, for example, the degree of consensus among the member states. Affording this sort of variable margin of appreciation usefully accommodates a limited range of pluralism. It does not permit domestic courts to fully ignore the supranational pronouncement (though domestic courts have sometimes asserted greater independence). Nevertheless, it does allow space for local variation, particularly when the law is in transition or when no consensus exists among member states on a given issue. Moreover, by framing the inquiry as one of local consensus, the margin of appreciation doctrine disciplines the ECtHR and forces it to move incrementally, pushing toward consensus without running too far ahead of it. Finally, the margin of appreciation functions as a signalling mechanism, through which 'the EC $[t] H R$ is able to identify potentially problematic practices for the contracting states before they actually become violations, thereby permitting the states to anticipate that their laws may one day be called into question' (Helfer and Slaughter 1997: 317). And, of course, there is reverse signalling as well, because domestic states, by their societal evolution away from consensus, effectively maintain space for local variation. As Laurence Helfer and Anne-Marie Slaughter (1997: 317) have observed, 'The conjunction of the margin of appreciation doctrine and the consensus inquiry thus permits the EC[t]HR to link 
its decisions to the pace of change of domestic law, acknowledging the political sovereignty of respondent states while legitimizing its own decisions against them'.

Whereas the margin of appreciation doctrine is a way of working out relationships among different communities, a second example of pluralist procedural doctrines involves hybridizing the decisionmaking body or process itself. For example, from 1190 until 1870, English law used the so-called 'mixed jury', or 'jury de medietate linguae', with members of two different communities sitting side by side to settle disputes when people from the two communities came into conflict (Constable 1994; Ramirez 1994: 781). Mixed juries were also used in disputes between Jews and Christians, city and country dwellers, and merchants and non-merchants. In the human rights arena, hybrid domestic/ international courts continue the tradition of the mixed jury. Such hybrid courts have been employed in transitional justice settings in Kosovo, East Timor, Sierra Leone, and Cambodia. In these courts domestic judges - ideally drawn from the multiple political, racial, or ethnic groups involved in the larger geopolitical conflict - sit alongside international judges, and domestic and international lawyers also work together to prosecute the cases.

Scholars suggest that, at least in theory, hybrid courts hold the promise of addressing some of the problems encountered in post-conflict settings by wholly international courts on the one hand, and wholly domestic courts on the other (Dickinson 2003b). Such problems can be grouped into three categories: legitimacy, capacity building and norm penetration. With regard to legitimacy concerns, the rationale for hybrid courts is largely the same as for mixed juries. If there is broad representation from the various communities involved in the dispute, then the outcome of the trial is more likely to be palatable to a cross-section of the population. Moreover, the presence of judges from the broader international community may contribute to a sense of fairness both for others watching the process from afar and for domestic populations who fear that local judges will rule based on sectarian prejudices. On the other hand, the presence of local judges may protect against rejection of the court as wholly 'foreign', a perception that has, for example, bedevilled the international court for the former Yugoslavia. A hybrid court may therefore be seen as the best available compromise. Turning to capacity building, a hybrid court physically located in the region may be preferable to an international court elsewhere because resources both for physical infrastructure and for training will be more likely to flow into the country. Finally, scholars argue, hybrid courts may help train a cadre of domestic lawyers in international legal standards and give them the tools necessary to develop and adapt those international norms in local settings. Meanwhile, the international actors are more likely to understand better the local nuances that may complicate the application of universal norms. It should be noted that, even if hybrid courts have failed to fully live up to their promise, they may still be preferable to wholly international or wholly domestic courts for many of the reasons set forth above. In any event, a hybrid court will often be the only viable political compromise, reflecting - as with many pluralist solutions the impracticality of wholly universalist or wholly territorialist responses and the resulting need for some sort of hybrid mechanism. Moreover, as Stephen Krasner (2005: 76) has theorized, the sort of 'shared sovereignty' reflected in the hybrid court structure can be particularly important when domestic institutions are weak because it can 'gird new political structures with more expertise, better-crafted policies, and guarantees against abuses of power'. Following this logic, the Dayton Accords effectively made the Bosnian Constitutional Court a hybrid court, authorizing the President of the European Court of Human Rights to appoint three non-Bosnian judges to the nine-member court. A different kind of hybrid is the Israeli Supreme Court, which has, since its inception, customarily had at least one member who is an expert in Jewish law. Thus, we can see that global legal pluralism does in fact point in a distinctive pluralist direction. As a result, it is a perspective that affords both a way of evaluating existing doctrines and institutions and a way of 
designing new ones along lines that are distinct from the traditional focus on formal authority, and coercive power.

But is this vision pluralist enough? One might think that there is still too much attention paid to the interaction of formal governmental and juridical actors and institutions. Thus, in the examples above, committed pluralists would decry the relentless reference to official courts, juries, judges, and processes. A truly pluralist account would focus on non-governmental activities as well. After all, part of the point of pluralism is to broaden the lens to include less formal normgenerating activities. Some of this problem, however, simply results from the biases inherent in data collection. In looking for evidence of how a legal or quasi-legal regime operates, it is always easier to gather information about more formal regimes because records are more widely disseminated, official media outlets tend to report on them, and so on. In contrast, less official venues for legal norms tend to require more detailed ethnographies or other forms of empirical, on-the-ground data collection. Nevertheless, most of the normative principles undergirding global legal pluralism would apply to non-state communities as well. These communities can establish decision-making institutions and procedural mechanisms that encourage consideration of alternative communities and their norms, and they can embed permanent forms of structural interaction. Indeed, many scholars have in fact examined such non-state communities, in realms as disparate as the codes governing jewellery merchant enclaves (Bernstein 1992), tuna sellers (Feldman 2006), gypsies (Weyrauch and Bell 1993), the Internet Engineering Task Force (Froomkin 2003: 792-4), and the Gentleman's Agreement of bankers concerning export credits (Levit 2005). In the end, it is clear that global legal pluralism at the very least offers a useful framework to ensure both that we identify these non-state law-making communities and analyze legal procedures and institutions through the lens of pluralist principles.

Finally, one might ask whether this proceduralist pluralist vision is simply liberalism in another guise and not really pluralism at all (Galán and Patterson 2013). After all, liberalism is not unalterably opposed to non-state norms, and even those who focus only on the central legal authority of the liberal state think it important that the state sometimes defer to such norms. Indeed, one of the core notions of liberalism is that government should not take sides in debates about competing visions of the good, and so space is allowed for non-state normative commitments. So long as a non-state normative community does not infringe unduly on the rights of others, liberalism allows those communities a tremendous amount of freedom and scope. For their part most pluralists do not deny the importance of the state, nor even the fact that often the state has greater coercive power at its disposal and therefore is better able to enforce its norms than non-state entities. After all, recognizing non-state lawmaking as important does not in and of itself mean that all sources of law are equally powerful or influential. So, on the surface it appears that legal pluralism and legal liberalism effectively merge into one. The merged statement goes something like this: "The state is the most powerful lawmaker; it allows scope for non-state norms when it chooses to, and it often does choose to defer because non-state norms have a strong emotional pull and should be accorded deference as long as those norms don't get out of hand.' And if that's all legal pluralism is adding, then the voluminous legal pluralism scholarship does not appear to have altered the basic liberal legal framework very much.

Responding to this objection requires a longer treatment (for a preliminary take on this issue, see Berman 2013), but for these purposes I will simply suggest that legal pluralism is in fact significantly different from the classic liberal vision in at least two important ways, one descriptive and one normative. First, as a descriptive matter (and again it is important to recognize that legal pluralism was historically a descriptive project) legal pluralists are far more likely than traditional liberals even to notice the pluralism of legal and quasi-legal norms that exist apart from the state. A 
liberal institutionalist will tend to focus on state-based formal entities exclusively and will therefore analyze non-state normative communities only when such communities assert rights before those entities or when those communities propagate norms that seem to present major conflicts with the state. Thus, the low-level day-to-day interaction of normative communities will tend to disappear from view. Moreover, when non-state norms do arise, the question is often framed only in terms of how much the state should defer to or tolerate the non-state community, not as a true conflict of normative systems. Thus, the state-centric view will tend to miss much that legal pluralism uncovers and will bias the analytical framework from the start.

Second, as legal pluralism has developed a more normative bite, it has been used to justify procedural mechanisms, institutional designs and discursive practices aimed at developing habits of mind in decision makers that will encourage those decision makers to use restraint in insisting jurispathically on their own norms to the exclusion of the norms of other communities. Thus, the key normative question from a pluralist perspective is not simply: here are my norms, now how much should I tolerate others? Instead, as discussed above, pluralists will favour hybrid institutional designs and practices that will embed such principles of toleration and accommodation into dayto-day operations. These designs and practices may well be consonant with liberalism, but they result in a very different set of institutional arrangements, inquiries and jurisprudential tropes. For example, consider a governing council of decision makers popularly elected by citizens of a community. Assume that every council member happens to be a member of the same majority ethnic, racial or religious group within that broader community. If the election were conducted fairly and the governing body does not unduly infringe minority rights in its substantive decisions, then under most theories of liberalism of which I am aware there is at least some justification for saying that this is a legitimate arrangement. If one embraces the vision of legal pluralism I pursue, however, one might reach the conclusion that even if this rule solely by members of the dominant group is legitimate, it is likely not preferable. This is because the procedural pluralist approach adds in a preference for greater dialogue among multiple communities to improve the quality of decision making, to build habits of mind that inculcate tolerance and to make it more likely that the minority will acquiesce in whatever substantive decisions are ultimately reached. Accordingly, following a more pluralist approach, one might decide to set aside certain seats on the governing council for the minority group. Either of these arrangements is likely compatible with liberalism; however, the pluralist perspective adds an additional set of considerations to weigh in the institutional design decision. Of course there are liberal theorists who would similarly seek structural accommodation to minority groups of this sort (see, e.g., Kymlicka 1995). But the point is that a pluralist approach tends to direct our gaze towards the prudential reasons that hybrid mechanisms of this sort might be desirable.

Thus, in the end I believe global legal pluralism offers a fundamentally different analytical framework - both descriptively and normatively - from liberalism. And while it may be that a pluralist perspective can fit comfortably within a liberal philosophical stance (that depends on how far the pluralist impulse is pushed in particular cases), I think a pluralist approach is likely to lead to both a more nuanced descriptive understanding of the world and a more desirable legal and political framework for addressing the hybridity that surrounds us every day.

\section{Conclusion}

Legal pluralism has long been a useful trope to force scholars away from assuming that all law resides in the sovereign. The move to global legal pluralism allows more detailed analysis of 
all the ways in which international and transnational legal and quasi-legal pronouncements have potential impact regardless of whether the pronouncements are accompanied by the threat of coercive force. In addition, the normative project of global legal pluralism allows the evaluation of institutions and procedures based on how well they accommodate multiple voices from multiple communities. Thus, global legal pluralism offers a distinctive and useful set of inquiries for understanding the complex multifaceted ways in which law is deployed in the twenty-first century. And Roger Cotterrell, through his decades-long exploration of how social theory contributes to an understanding of law, has ably guided us towards this more nuanced understanding of law in all its plural forms, all around the globe.

\section{Bibliography}

Ahdieh, R. 2004. 'Between Dialogue and Decree: International Review of National Courts'. 79 New York University Law Review, 2029-163.

Benda-Beckmann, F. 1997. 'Citizens, Strangers, and Indigenous Peoples: Conceptual Politics and Legal Pluralism'. 9 Law and Anthropology, 1-42.

Berger, T. 1998. Cultures of Antimilitarisn: National Security in Germany and Japan. Baltimore, John Hopkins University Press.

Berman, P. Schiff 2002. 'The Globalization of Jurisdiction'. 151 University of Pennsylvania Law Review, 311-529.

Berman, P. Schiff 2007. 'Global Legal Pluralism'. 80.6 Southern California Law Review, 1155-238.

Berman, P. Schiff 2009. 'The New Legal Pluralism'. 5 Annual Review of Law \& Social Science, 225-42.

Berman, P. Schiff 2012. Global Legal Pluralism: A Jurisprudence of Law Beyond Borders. Cambridge, Cambridge University Press.

Berman, P. Schiff 2013. 'How Legal Pluralism Is and Is Not Distinct from Liberalism: A response to Alexis Galán and Dennis Patterson'. 11 International Journal of Constitutional Law, 801-8.

Bernstein, L. 1992. 'Opting Out of the Legal System: Extralegal Contractual Relations in the Diamond Industry’. 21 Journal of Legal Studies, 115-57.

Bumiller, K. 1988. The Civil Rights Society: the Social Construction of Victims. Baltimore, John Hopkins University Press.

Constable, M. 1994. The Law of the Other: the Mixed Jury and Changing Conceptions of Citizenship, Law, and Knowledge. Chicago, University of Chicago Press.

Cotterrell, R. 1995. Law's Community: Legal Theory in Sociological Perspective. Oxford, Oxford University Press.

Cotterrell, R. 2006. Law, Culture, and Society: Legal Ideas in the Mirror of Social Theory. Aldershot, Ashgate.

Cover, R. 1981. 'The Uses of Jurisdictional Redundancy: Interest, Ideology, and Innovation'. 22.4 William \& Mary Law Review, 639-82.

Dickinson, L. 2003a. 'The Dance of Complementarity: Relationships among Domestic, International, and Transnational Accountability Mechanisms in East Timor and Indonesia'. In J. Stromseth (ed.), Accountability for Atrocities: National and International Responses. Ardsley, New York, Transnational.

Dickinson, L. 2003b. 'The Promise of Hybrid Courts'. 97 American Journal of International Law, 295-310. 
Ellickson, R. 1991. Order Without Law: How Neighbors Settle Disputes. Cambridge, MA, Harvard University Press.

Ewick, P. and Silbey, S. 1998. The Common Place of Law: Stories from Everyday Life. Chicago, University of Chicago Press.

Feldman, E. 2006. 'The Tuna Court: Law and Norms in the World's Premier Fish Market'. 94 California Law Review 313-69.

Figgis, J.N. 1913. Churches in the Modern State. London, Longmans, Green and Co.

Finnemore, M. 1996. National Interests in International Society. Ithaca, New York, Cornell University Press.

Franck, T. 1996. 'Clan and Superclan: Loyalty, Identity and Community in Law and Practice'. 90 American Journal of International Law, 359-83.

Froomkin, A. Michael. 2003. 'Habermas@Discourse.Net: Toward a Critical Theory of Cyberspace'. 116 Harvard Law Review, 749-873.

Galán, A. and Patterson, D. 2013. 'The Limits of Normative Legal Pluralism: Review of Paul Schiff Berman, Global Legal Pluralism: A Jurisprudence of Law beyond Borders'. 11 International Journal of Constitutional Law, 783-800.

Galanter, M. 1981. 'Justice in Many Rooms: Courts, Private Ordering, and Indigenous Law'. 19.1 Journal of Legal Pluralism \& Unofficial Law, 1-48.

Geertz, C. 1983. Local Knowledge: Further Essays in Interpretive Anthropology. New York, Basic Books.

Gordon, R. 1984. 'Critical Legal Histories'. 36 Stanford Law Review, 57-125.

Griffiths, J. 1986. 'What is Legal Pluralism?' 24(1) Journal of Legal Pluralism \& Unofficial Law, 1-50.

Helfer, L. and Slaughter, A-M. 1997. 'Toward a Theory of Effective Supranational Adjudication'. 107 Yale Law Journal, 273-391.

Hooker, M. 1975. Legal Pluralism: An Introduction to Colonial and Neo-Colonial Laws. Oxford, Clarendon Press.

Jolls, C., Sunstein, C and Thaler, R. 1998. 'A Behavioral Approach to Law and Economics'. 50/5 Stanford Law Review, 1471-550.

Krasner, S. 2005. 'The Case for Shared Sovereignty'. 16/1 Journal of Democracy, 69-83.

Kymlicka, W. 1995. Multicultural Citizenship: A Liberal Theory of Minority Rights. Oxford, Oxford University Press.

Levit, J.K. 2005. 'A Bottom-Up Approach to International Lawmaking: The Tale of Three Trade Finance Instruments'. 30/1 Yale International Law Review, 125-209.

Maitland, F.W. 1936. 'Trust and Corporation'. In Maitland: Selected Essays. Edited by H. Hazeltine, G. Lapsley and P. Winfield. Cambridge, Cambridge University Press, 141-222.

McCann, M. 1994. Rights at Work: Pay Equity Reform and the Politics of Legal Mobilization. Chicago, University of Chicago Press.

Merry, S.E. 1988. 'Legal Pluralism'. 22 Law \& Society Review, 869-96.

Merry, S.E. 1990. Getting Justice and Getting Even: Legal Consciousness among Working-Class Americans. Chicago, University of Chicago Press.

Merry, S.E. and Stern, R. 2005. 'The Female Inheritance Movement in Hong Kong: Theorizing the Local/Global Interface.' 46/3 Current Anthropology, 387-410.

Obiora, L. Amede. 1997. 'Bridges and Barricades: Rethinking Polemics and Intransigence in the Campaign Against Female Circumcision'. 47 Case Western Reserve Law Review, 275-378.

Orentlicher, D. 1991. 'Settling Accounts: The Duty to Punish Human Rights Violations of a Prior Regime’. 100 Yale Law Journal, 2537-615. 
Osofsky, H. 2007. 'Climate Change Litigation as Pluralist Legal Dialogue?' 26 Stanford Journal of International Law, 181-238.

Pospisil, L. 1981. 'Modern and Traditional Administration of Justice in New Guinea'. 19 Journal of Legal Pluralism and Unofficial Law, 93-116.

Rajagopal, B. 2003. International Law from Below: Development, Social Movements, and Third World Resistance. Cambridge, Cambridge University Press.

Ramirez, D. 1994. 'The Mixed Jury and the Ancient Custom of Trial By Jury De Medietate Linguae: A History and a Proposal for Change.' 74/5 Boston University Law Review, 777-818.

Rivkin, D. Jr. and Casey, L. 2003. 'Crimes Outside the World's Jurisdiction'. New York Times, July 22, at A19.

Santos, B. de Sousa. 1987. 'Law: A Map of Misreading. Towards a Post-Modern Conception of Law'. 14/3 Journal of Law \& Society, 279-99.

Santos, B. de Sousa. 2002. Toward a New Legal Common Sense: Law, Globalization, and Emancipation. London, Butterworths/LexisNexis.

Sarat, A. and Kearns, T.R. 1993. 'Beyond the Great Divide: Forms of Legal Scholarship and Everyday Life'. In A. Sarat and T.R. Kearns (eds), Law in Everyday Life, 21.

Sarat, A. and Simon, J. 2001. 'Beyond Legal Realism? Cultural Analysis, Cultural Studies, and the Situation of Legal Scholarship'. 13 Yale Journal of Law and the Humanities, 3-32.

Silbey, S. 1992. 'Making a Place for Cultural Analyses of Law'. 17/1 Law and Social Inquiry, 39-48.

Tamanaha, B. 1993. 'The Folly of Legal Pluralism'. 20 Journal of Law \& Society, 192-217.

Vanderlinden, J. 1989. 'Return to Legal Pluralism'. 28 Journal of Legal Pluralism \& Unofficial Law, 149-57.

Wynter, S. 1997. "Genital Mutilation" or "Symbolic Birth"? Female Circumcision, Lost Origins, and the Aculturism of Feminist/Western Thought'. 47/2 Case Western Reserve Law Review, 501-52. 